\title{
Continental freshwater carbonate coated grains: oncoids in Quaternary deposits of the Serra da Bodoquena region, Central-West Brazil
}

\author{
Adelita Carolina Rodrigues ${ }^{1,2}$ (D), Larissa da Rocha Santos ${ }^{1,3}$ (D), Leonardo Fadel Cury ${ }^{1}$ (D), \\ Anelize Bahniuk Rumbelsperger ${ }^{1}$ (1)
}

\begin{abstract}
Oncoid nucleation and growth have been attributed to microorganism activity, commonly cyanobacteria, resulting in the trapping of organic, bioclastic or lithoclastic nuclei by concentric laminations. However, the factors controlling these processes are not well understood, especially regarding freshwater precipitation systems. Freshwater oncoids from alluvial terraces underlying paludal tufas in Quaternary carbonate deposits in Central-West Brazil (Bodoquena downstream plains) were submitted to petrological studies by optical microscope, $\mathrm{x}$-ray diffraction and fluorescence, scanning electron microscopy and C\&O stable isotopes analyses. Biogenic structures where well-preserved cyanobacteria EPS sheath structures suggest in vivo precipitation by $\mathrm{CO} 2$ concentrating mechanisms, whereas smooth rhomb calcite crystals likely indicate post mortem precipitation. The four identified morphologic features of spherical and subspherical oncoid types suggest growing in a shallow water body, with constant laminar flow and the absence of predators. The chemical and isotopic composition of the oncoids may represent nucleation and growth under relatively milder climatic conditions than today. This oncoid nucleation system may bring valuable information about climatic changes in Central-West Brazil (Tropical South Hemisphere) at the end of the Pleistocene and the beginning of the Holocene.
\end{abstract}

KEYWORDS: freshwater oncoids; continental carbonates; cyanobacteria calcification; microbial; EPS sheath structures.

\section{INTRODUCTION}

Oncoids are carbonate-coated grains produced by microorganism activity, commonly cyanobacteria, resulting in the trapping of organic, bioclastic, or lithoclastic nuclei by concentric laminations (Logan et al. 1964, Dahanayake 1978, Flügel 2010). Although the term 'oncoids' does not represent a genetic terminology, it is commonly used to refer to nodular coated grains formed by microbial activity (Flügel 2010).

As a microbialite and a carbonate coated grain, oncoids generally can bring palaeoclimatic and palaeoenvironmental information (Védrine et al. 2007, Zhang et al. 2015, Sequero et al. 2020) since they require specific factors for their full development, the most critical including:

- incidence of light that allows cyanobacterial colony growth, (Leinfelder and Hartkopf-Fröder 1990, Hägele et al. 2006);

\footnotetext{
${ }^{1}$ Lamir Institute, Geology Department, Universidade Federal do Paraná - Curitiba (PR), Brazil. E-mails: adelita.carolina15@gmail.com, anelize. bahniuk@ufpr.br, lrsantos.geo@gmail.com,cury@ufpr.br, anelize. bahniuk@ufpr.br

${ }^{2}$ Graduate Program of Geology, Universidade Federal do Paraná Curitiba (PR), Brazil.

${ }^{3}$ Postgraduate Program of Geology, Universidade Federal do Paraná Curitiba (PR), Brazil.

${ }^{*}$ Corresponding author.
}

- water body features such as depth, temperature, energy and low sedimentary input that enable nucleation and allow the development of a variety of morphologies and sizes (Logan et al. 1964, Riding 1975, Dahanayake 1978, Hägele et al. 2006, Védrine et al. 2007, Zhang et al. 2015);

- physicochemical conditions of the water and atmosphere that provide resources for cyanobacteria calcification, also predicting the oncoid framework (Merz 1992, Merz-Preiß and Riding 1999, Riding 2006, Sequero et al. 2020);

- lack of predators and competitive biota, enabling the oncoids' nucleation and growth in a free-competition/ predation environment (Riding and Awramik 2000, Hägele et al. 2006, Riding 2006).

This study focuses on cool freshwater oncoids, up to $10 \mathrm{~mm}$ long, found in the alluvial terraces of the Formoso River, Serra da Bodoquena region in Central-West Brazil. The aims of this work were:

- describing the oncoid occurrences in the alluvial terraces of the Formoso River;

- identifying the factors controlling their growth, with particular reference to microbial activity;

- understanding the oncoids' significance in the regional Quaternary carbonate deposits context, considering that oncoids have only been reported to occur stratigraphically below tufas (paludal and riverine). 
Through the evaluation of the main factors influencing the oncoid nucleation and growth in the Serra da Bodoquena Region, we suggest an old nucleation context for those carbonate-coated particles that involves climatic changes in the southern hemisphere during the Quaternary Period.

\section{BACKGROUND}

\section{Geological setting}

The studied oncoid occurrences are located at Serra da Bodoquena ( $\left.21^{\circ} 15^{\prime} \mathrm{S}, 56^{\circ} 34^{\prime} \mathrm{W}\right)$, in the Paraguay Fold Belt, southwest of the Pantanal wetlands (Mato Grosso do Sul State, Brazil). The Serra da Bodoquena (Fig. 1) is a geomorphological domain constituted of a set of hills reaching elevation of $800 \mathrm{~m}$, distributed over a $220 \mathrm{~km}$ long and $40 \mathrm{~km}$ wide N-S-trending structure, considered a carbonate plateau sustained by the Neoproterozoic metacarbonates, metapelites, and metapsammitic rocks of the Corumbá Group (Boggiani et al. 1993, Oliveira et al. 2017).

The Serra da Bodoquena is drained by several streams and creeks in which one example is the Formoso River and its tributaries that drain the Eastern Bodoquena ridge. The rivers' freshwater dissolves the metacarbonate rocks of the Corumbá Group and forms a karstic system, providing the carbonatic source for the Quaternary carbonate precipitation on the downstream plains (Boggiani et al. 1993, Sallun Filho et al. 2009a, Oliveira et al. 2017).

The downstream Quaternary deposits are formed due to bicarbonate and calcium ion precipitation. However, they show many particularities involving biological activity and geomorphological relief features (Oste et al. 2021).

The tufa deposits along the Formoso river are proposed to be included in the Pleistocene-Holocene Serra da Bodoquena Formation (Sallun Filho et al. 2009a), (Fig. 1) and it is subdivided into two members: Rio Formoso (riverine tufas) and Fazenda São Geraldo (paludal tufas) members. The Rio Formoso Member includes both active and inactive riverine tufa deposits (Sallun Filho et al. 2009a).

- The paludal tufas consist of friable micrite deposits occurring on river banks (Boggiani et al.2002), possibly formed in oxbow lakes (Boggiani et al. 2002, Utida et al. 2017) of 6,530 to $6,310 \mathrm{yr} \mathrm{BP}$ age $\left({ }^{14} \mathrm{C}, 21^{\circ} 15^{\prime} \mathrm{S}, 56^{\circ} 34^{\prime} \mathrm{W}\right.$ ) (Sallun Filho et al. 2009b);

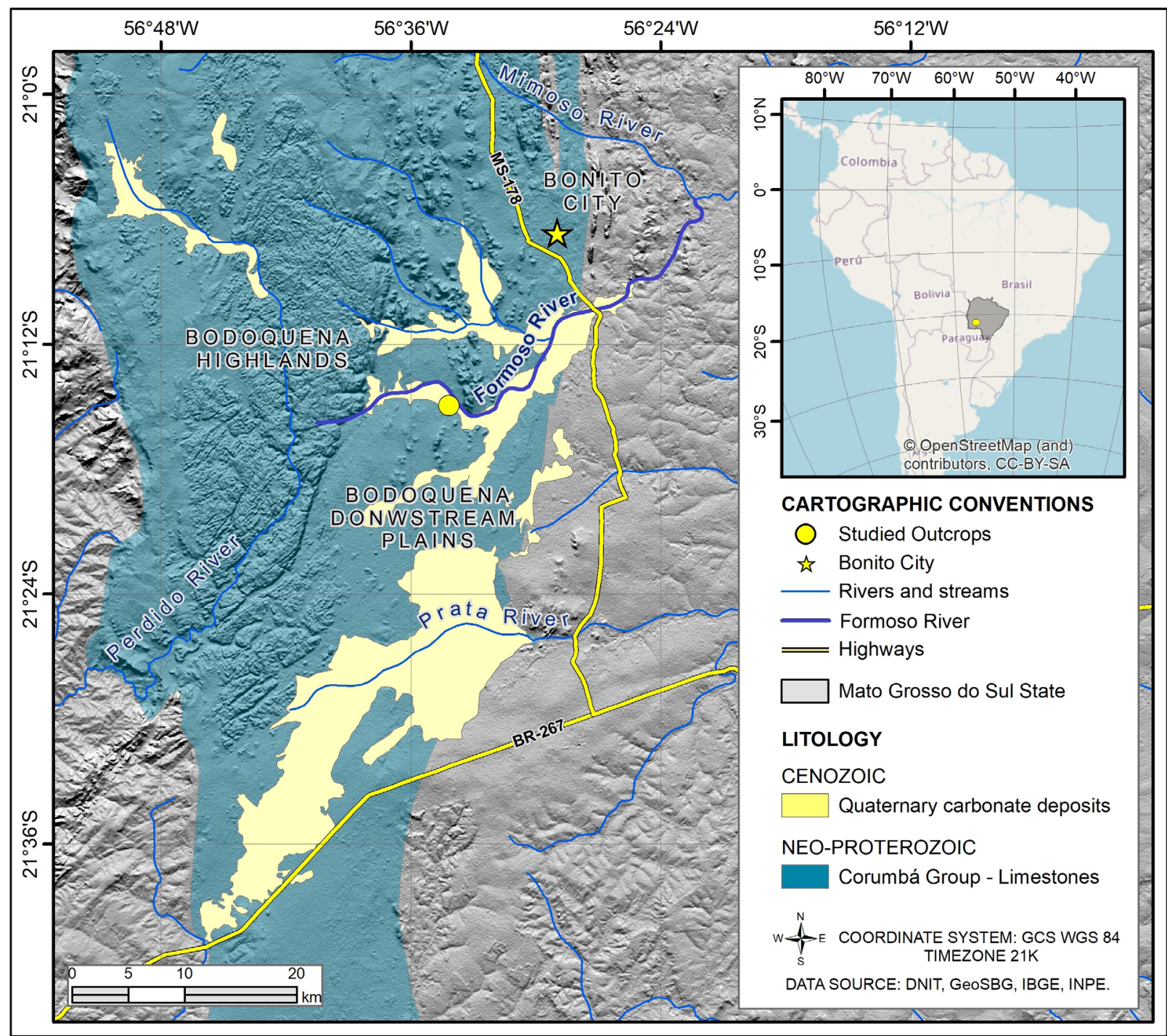

Figure 1. A. Geological context and location of the studied outcrops near Serra da Bodoquena Highlands. 
- The riverine tufa deposits occur in dams and waterfall settings, where the inactive tufa provided ages from 2,130 to 3,410 yr BP $\left({ }^{14} \mathrm{C}, 21^{\circ} 02^{\prime} \mathrm{S}, 56^{\circ} 51^{\prime} \mathrm{W}\right)$ (Sallun Filho et al. $2009 \mathrm{~b}$ ), forming stratified deposits recording the annual deposition cycle, with increasing growth in warm and rainy periods and decrease or absence of growth during cold periods (Boggiani et al. 2002, Sallun Filho et al. 2009a, Oliveira et al. 2017).

The active and inactive tufas are porous, displaying a wide range of structures related to macrophyte growth (mainly bryophytes) and microorganisms. The main facies are described as stromatolitic and phytoherm boundstone, phytoclastic rudstones, as well as oncoidal grainstones and rudstones (Oliveira et al. 2017, Oste et al. 2021).

The Serra da Bodoquena region is located in Tropical South America, commonly referred as the atmosphere's 'walker' circulation zone (Baker et al. 2001). The region is considered the most sensitive to atmospheric variation and important for paleoclimatic reconstruction using oxygen isotope record (\%o, V-PDB, V-SMOW) correlated to insolation $\left(\mathrm{W} \mathrm{m}^{-2}\right)$ in U/Th dated samples (Baker et al. 2001, Wang et al. 2004, Cruz Jr. et al. 2005, Seltzer et al. 2014, Novello et al. 2019) while using a pollen sedimentary record (Absy et al. 1991, Ledru 1993, Whitney et al. 2011).

\section{Cyanobacteria related to oncoids}

The cyanobacteria are wrapped in a biofilm known as EPS (protective extracellular polymeric substance) (Riding and Awramik 2000, Decho et al. 2005, Riding 2006) that is able to catalyze calcium carbonate $\left(\mathrm{CaCO}_{3}\right)$ precipitation (Decho et al. 2005, Dupraz and Visscher 2005, Dupraz et al. 2009).

The cyanobacteria colonization coupled with calcium carbonate precipitation might form concentric laminations around a lithoclastic or bioclastic nuclei resulting in a carbonate-coated grain (Logan et al. 1964, Dahanayake 1978).

Considering that carbonate precipitation and its mediation by biological activity are the core of oncoid nucleation and growth, the ecosystem present in the freshwater coated grains or oncoids are suitable for a series of environmental paleoclimatic interpretations.

Under this classification, the coated grains described as oncoids were previously interpreted as related to organisms from Nostocales order (Rivularia, Calothrix, Schizothrix, Phormidium) (Riding 1975, Pentecost 1978, Pentecost and Talling 1987, Hägele et al. 2006). In particular, the Rivularia genera was considered a bioindicator or environmental proxy since its proliferation is generally restricted to specific physical-chemical parameters (Perona and Mateo 2006, Berrendero et al.2008, Oren 2015, Shalygin et al.2018), even being reported in a series of ecological niches as freshwater, terrestrial, and marine environments (Berrendero et al. 2008).

\section{METHODS}

The studied oncoids were collected in the Formoso river alluvial terraces (GCS WGS84: Longitude 56³', Latitude $\left.21^{\circ} 1^{\prime}\right)$, occurring as rudstones and floatstones, overlaid by the paludal tufas (Fig. 2).

Four oncoids that represent each morphology type and one well-cemented floatstone were selected for petrographic studies in thin sections using the Zeiss Stereo microscopic model at Lamir Institute (LAMIR at the Federal University of Parana), and an Olympus BX51 at CTAF Institute (Centro de Tecnologias Avançadas em Fluorescência - Biology Department, Universidade Federal do Paraná). The sample descriptions followed the Dunham limestone classification (1962) modified by Embry and Klovan (1971), and the coated grains' classification followed Flügel (2010) descriptive terminology (Dunham 1962, Embry and Klovan 1971, Flügel 2010).

To evaluate the presence of biological activity and to describe the oncoids' internal laminations, scanning electron microscopic (SEM) analyses were conducted using a JEOL SEM model 6010LA, equipped with an energy dispersive $\mathrm{X}$-ray spectrometer. One lithified rudstone, and six oncoidal fragments representative of morphology types and nuclei composition were Au-coated before the SEM examination, and the analyses were conducted with an accelerating voltage of $20 \mathrm{kV}$ using the minimum beam diameter. In addition, three morphology representative samples were selected to be evaluated in a SEM TESCAN VEGA 3 LMU, EDS type chemical analysis system (Oxford) using the AZ Tech software (Advanced) with $80 \mathrm{~mm}^{2}$ SDD type detector.

Mineralogical and geochemical analyses were carried out at LAMIR with five total powdered samples ( 325 to $400 \mathrm{mesh}$ ), three oncoidal samples, and two lithified rudstones. The mineralogical composition was determined using X-ray diffraction (XRD) through a PANalytical diffractometer, Empyrean model with an $\mathrm{X}$-accelerator detector, equipped with a $\mathrm{Cu}$ tube. Scans from bulk samples were run from $2 \theta$ angles from 3 to $70^{\circ}$, using a step-size of $0.016^{\circ}$ and count time of $10.16 \mathrm{~s}$ per step. The chemical composition (wt\%) of the main oxides $(\mathrm{CaO}$, $\mathrm{MgO}, \mathrm{SiO}_{2}, \mathrm{Al}_{2} \mathrm{O}_{3}, \mathrm{Fe} 2 \mathrm{O}_{3}, \mathrm{Na}_{2} \mathrm{O}, \mathrm{K}_{2} \mathrm{O}, \mathrm{TiO}_{2}, \mathrm{MnO}$, and $\mathrm{P}_{2} \mathrm{O}_{5}$ ) and four trace elements $(\mathrm{Sr}, \mathrm{Ba}, \mathrm{S}$, and $\mathrm{Cl}$ ) were obtained via quantitative X-ray fluorescence through a PANalytical model Axiox-Max with Rh tube, using a lithium tetraborate fused bead.

$\mathrm{C}$ and $\mathrm{O}$ stable isotopes were conducted in a Gas Bench II and a Thermo Delta V Advantage mass spectrometer (ThermoFisher Scientific) using 400 to $600 \mu \mathrm{g}$ samples, digested with orthophosphoric acid at $72^{\circ} \mathrm{C}$ with. The results were referenced to the V-PDB scale using the following reference materials: NBS 19, IAEA-CO-1, IAEA-CO-8, and IAEA-CO-9. Standard deviation was reported $(1 \sigma)$ to the internal deviation of 8 to 10 readings of the same preparation.

\section{RESULTS}

\section{Facies description}

The studied deposits were described as fluvial terraces that flank the actual fluvial floodplain and the Formoso River's current stream, and the five main facies described were (Fig. 2): A basal layer of siliciclastic clay (Claystones) and four allochthonous calcareous facies that consist of oncoidal 


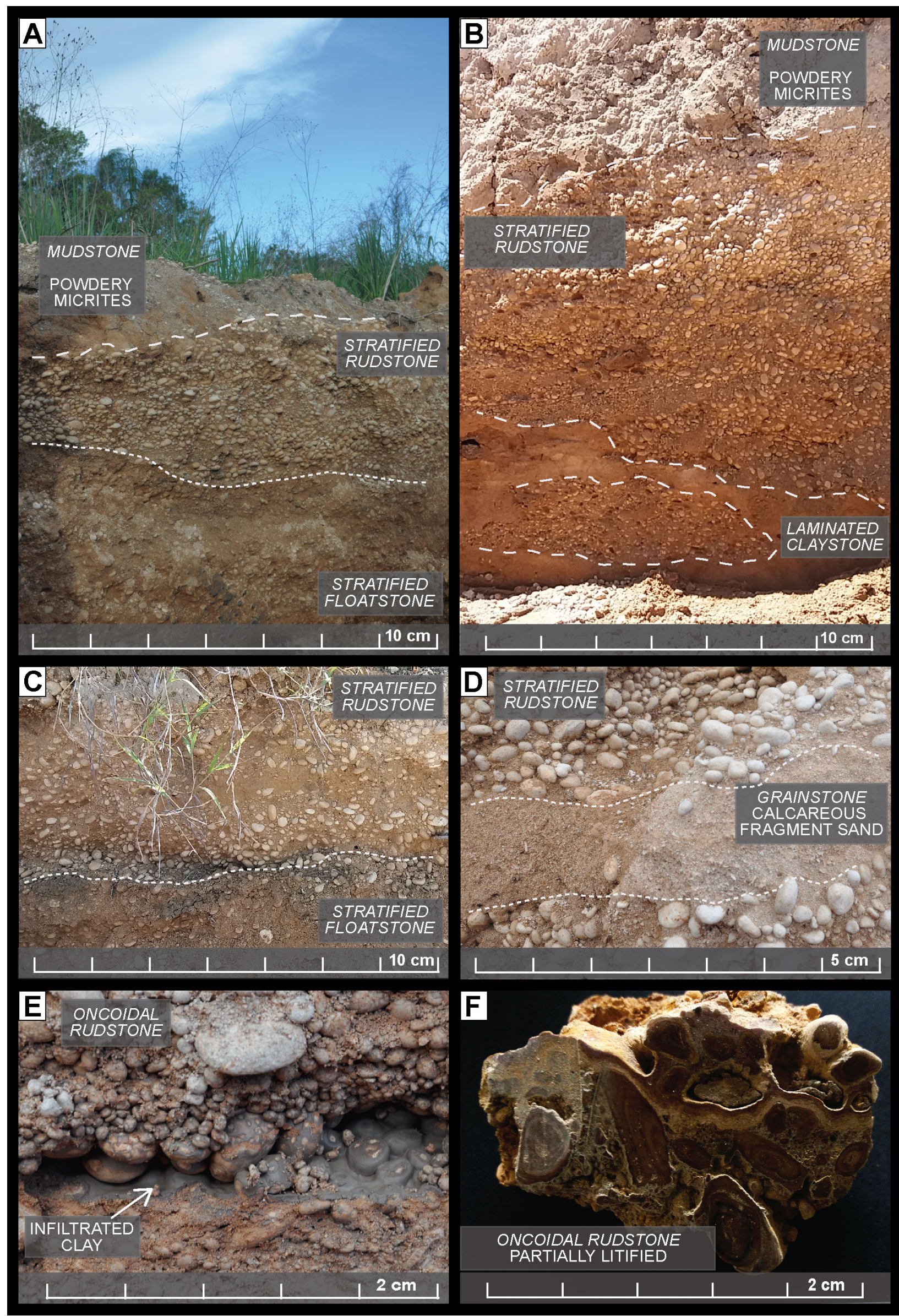

Figure 2. Outcrop view of the Formoso River alluvial terraces; (A) Rudstones (Rs) and floatstones (Fs) showing imbricated oncoid in a lateral view of trough cross-stratification, the massive mudstone $(\mathrm{Mm})$ overlies the oncoidal lenses; (B) Stratified rudstones (Rs), massive mudstones $(\mathrm{Mm})$, and laminated Claystone $(\mathrm{Cl})$ at the base; (C) Lenticular grainstone (Gl), composed of biogenic calcareous fragments in sand fraction, predominantly algae or macrophytes tubes, stalks and Mollusca shells; (D) Rudstones (Rs) and Floatstones (Fs) and their transitional contact (dashed line); (E) Oncoidal Rudstone lenses with infiltrated clay; (F) Transversal cut of oncolite hand-sample showing a bimodal distribution of the framework oncoids and early cementation features, found in small occurrences. 
lenses (Rudstones and Floatstones), calcareous sand lenses (Grainstones), and at the top occur a powdery micrites layer (Mudstones), as detailed below.

\section{Claystone facies - laminated clay (Cl)}

The massive to crudely laminated brown claystones in the studied terrace correspond to its basal interval with 0.5 to $1.5 \mathrm{~m}$-thick, and up to $10 \mathrm{~m}$ wide observed (Fig. $2 \mathrm{~B}$ ). The claystone has a poor plastic aspect and stratification is visible. Organic components such as carbonaceous fragments occur in smaller proportions (5\%). Oncoids with diameters $<2 \mathrm{~mm}$ were observed, dispersed at the upper part of the clay layers.

\section{Calcareous sand - stratified grainstone (Gs)}

The Gs facies occur in 10 to $30 \mathrm{~cm}$-thick highly friable lenses of biogenic carbonate fragments. The framework grain sizes range between 0,5 to $2 \mathrm{~mm}$, and fragments with 2 to $16 \mathrm{~mm}$ are make up $20 \%$ of the sample. The main composition is represented by calcified tubes of calcareous algae, stalks of macrophytes, calcified Mollusc shells, oncoids, and partially nucleated oncoidal fragments (Fig. 2D). The colors are whitish to yellowish.

\section{Oncoidal lenses - stratified rudstones and floatstones (Rs and Fs)}

The oncoidal facies occurs as 0.5 to $1.5 \mathrm{~m}$-thick up to $10 \mathrm{~m}$ wide highly friable lenses. The framework is constituted of oncoids ranging from $0,5 \mathrm{~mm}$ to $6 \mathrm{~cm}$, forming oncoidal rudstones and floatstones with medium-sized (up to $3 \mathrm{~m}$ ) through cross-stratification (Figs. 2A, 2B and 2C). The oncoids' sizes range from 0.5 to $6 \mathrm{~cm}$ on the $\mathrm{x}$-axis (longest length) up to $3 \mathrm{~cm}$ on the $y$ axis (height). The $\mathrm{z}$-axis, although variable, occurs with less thickness or the same size as the $\mathrm{x}$-axis size.

The rudstones and floatstones' matrix is comprised of bioclasts or limestone fragments in a sand fraction such as shells, calcified tubes of calcareous algae, smaller oncoids, or oncoidal fragments smaller than $2 \mathrm{~mm}$. Quartz grains partially encrusted with calcium carbonate are also common and the Floatstone matrix may also include clay. The proportions of brown clay are greater at the base of outcrops, gradually disappearing to the top. The rudstone facies are absent in clay.

In the stratified rudstone (Rs) facies lenses with infiltrated gray clay (Fig. 2E), of high plasticity occur. In the stratified floatstone (Fs) facies occurs a well-lithified layer around 10 to $30 \mathrm{~cm}$ - thick and $1 \mathrm{~m}$ wide (Fig. $2 \mathrm{~F}$ ).

\section{Mudstone facies - powdery micrites/massive mudstone (Mm)}

The $\mathrm{Mm}$ facies overlies the oncoidal facies (Figs. 2A and 2B), and it is composed of gray powdery micrites and calcareous fragments $(<10 \%)$ such as calcified Mollusc shells, calcareous algae tubes and macrophytes stalks. The Mm facies overlie the oncolytic facies through an abrupt contact. The Mm facies are highly friable with a massive structure, where Cyanobacteria filaments are encrusted with carbonate crystals.

\section{Oncoids morphologic features}

The oncoids were classified based on their shapes into four main types (Fig. 3):

- shape 1: includes oncoids showing triangular shapes, with concave tops, elliptical sides and no laminations at the base (Fig. 3A);

- shape 2: oncoids with triangular shapes and concave tops, thinner laminations on the base compared to top and side laminations (Fig. 3B);

- shape 3: oncoids with an elliptical shape and continuous laminations of similar thickness (Fig. 3C);

- shape 4: oncoids with spherical shapes, continuous and similar thick-sized laminations (Fig. 3D).

\section{Petrographic features}

Three internal structural patterns were distinguished in the studied oncoids (Fig. 4):

- massive micrite lamination with moldic porosity (Fig. 4A);

- bacterial shrub structure (Fig. 4A);

- layers with amorphous organic matter between laminations (Fig. 4B).

Their nuclei consist of sub-angular to sub-rounded (Fig. 4C), low to medium sphericity quartz grains (Fig. 4D), moldic microorganisms (Fig. 4E), moldic Mollusca shells including Bivalve and Gastropod Groups, as well as amorphous silica replacing relict nuclei (Fig. 4F). Early diagenetic features include mosaic calcite cement and microcrystalline iron oxides and hydroxides cement.

The oncoids also show continuous or discontinuous growth phases, sometimes with remnant oncoids eroded (Fig. 4G) as a new nucleus-substrate to a subsequent growing phase (Fig. 4H).

\section{Oncoid microfacies}

\section{Massive micrite with moldic porosity}

The massive micrite layers (Fig. 5) represent the main microfacies forming 100 to $400 \mu \mathrm{m}$-thick layers around the nucleus (Fig. 5A). The EPS sheath relict structures related to the cyanobacteria filaments occur throughout the lamination (Fig. 5B). The filament structures show $\sim 6 \mu \mathrm{m}$ in diameter and lengths of 50 to $250 \mu \mathrm{m}$ (Fig 5C). The related moldic porosity represents up to $7 \%$ of the sample. Smooth rhomb calcite crystals are also common (Fig. 5D), usually around $>20 \mu \mathrm{m}$, surrounded by subhedral crystal aggregates (Fig. $5 \mathrm{E}$ ). Rare cyanobacteria calcified filaments (Fig. $5 \mathrm{~F}$ ), up to $3 \mu \mathrm{m}$ in diameter, are observed in the massive micrite layers (Fig. 5G). Needle calcite crystals up to $2 \mu \mathrm{m}$ complete this textural pattern (Fig. 5H).

\section{Bacterial shrub}

The bacterial shrub structure forms discontinuous lamination (Fig. 6) and is usually responsible for irregularities in the oncoid shapes. When the bacterial shrub is well developed $(0.5$ to $1.5 \mathrm{~cm})$, there is a growth predominance on one side of the oncoid per growing cycle (Figs. 6A and 6B). 


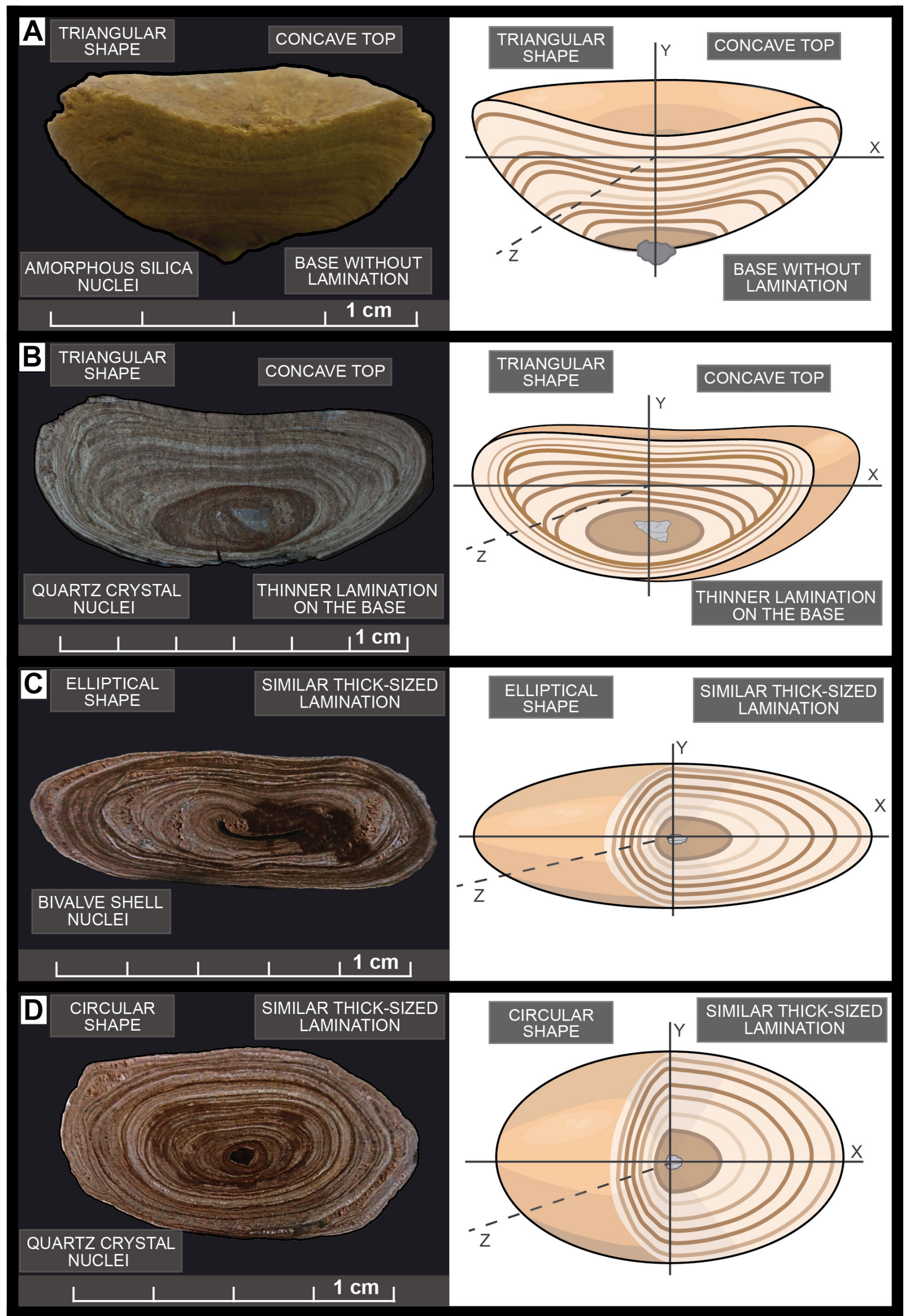

Figure 3. Oncoids' morphologic features. (A) Type 1, triangular, showing no laminations at the base or the concave top; (B) Type 2, triangular, showing a concave top and thin basal laminations; (C) Type 3, with elliptical shape, regular, continuous, and similar thick-sized laminations, slightly thicker at the sides; (D) Type 4, showing spherical shape, regular, continuous, and similar thick-sized laminations. Nucleus not used to indicate morphologic features; (A) Amorphous silicon nuclei; (B) Quartz crystal nuclei; (C) Moldic shell nuclei; (D) Quartz crystal nuclei. 

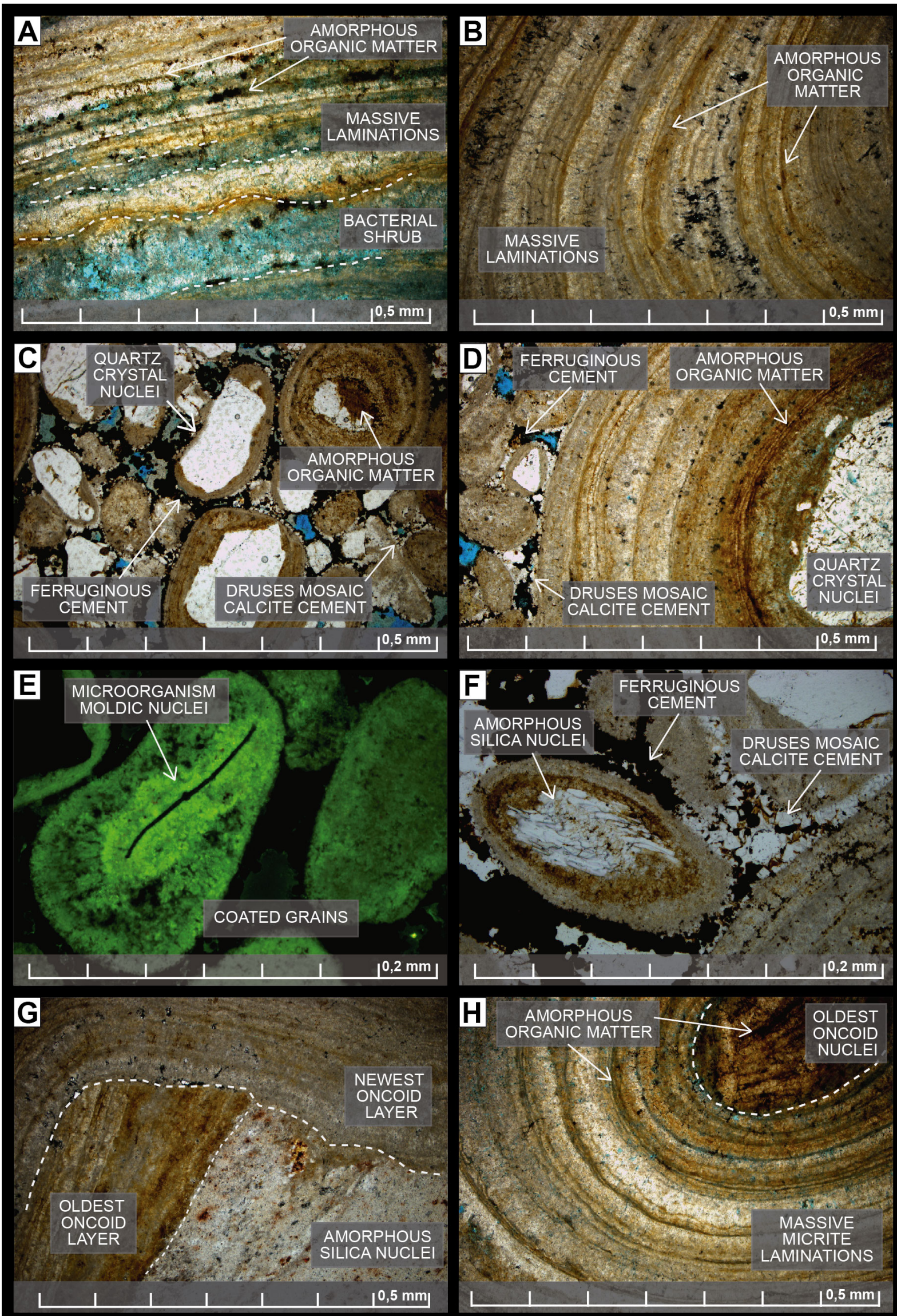

Figure 4. Examples of the main petrographic aspects of the studied oncoids (A, B, C, D, F, G, H) under natural light and (E) UV epifluorescence. (A) Alternating lamination cycles with massive and bacterial shrub laminations, porosity filled by amorphous organic matter; (B) Carbonate massive and concentric laminations, porosity filled by amorphous organic matter; (C) Carbonate coated grains with quartz crystal nucleus, early diageneses feature such as druses mosaic calcite, ferruginous cement; (D) Oncoids with carbonate concentric lamination around a quartz crystal nucleus, early diageneses features such as druses mosaic calcite and ferruginous cement. (E) Carbonate coated grains, detail for microorganism moldic porosity; (F) Carbonate coated grains with amorphous silica nuclei, early diageneses feature such as druses mosaic calcite and ferruginous cement; $(\mathrm{G})$ Carbonate massive and concentric laminations around the oldest oncoid nuclei, porosity filled by amorphous organic matter; $(\mathrm{H})$ Oncoid with more than one nucleation stages, amorphous silica substituting relict nuclei. 

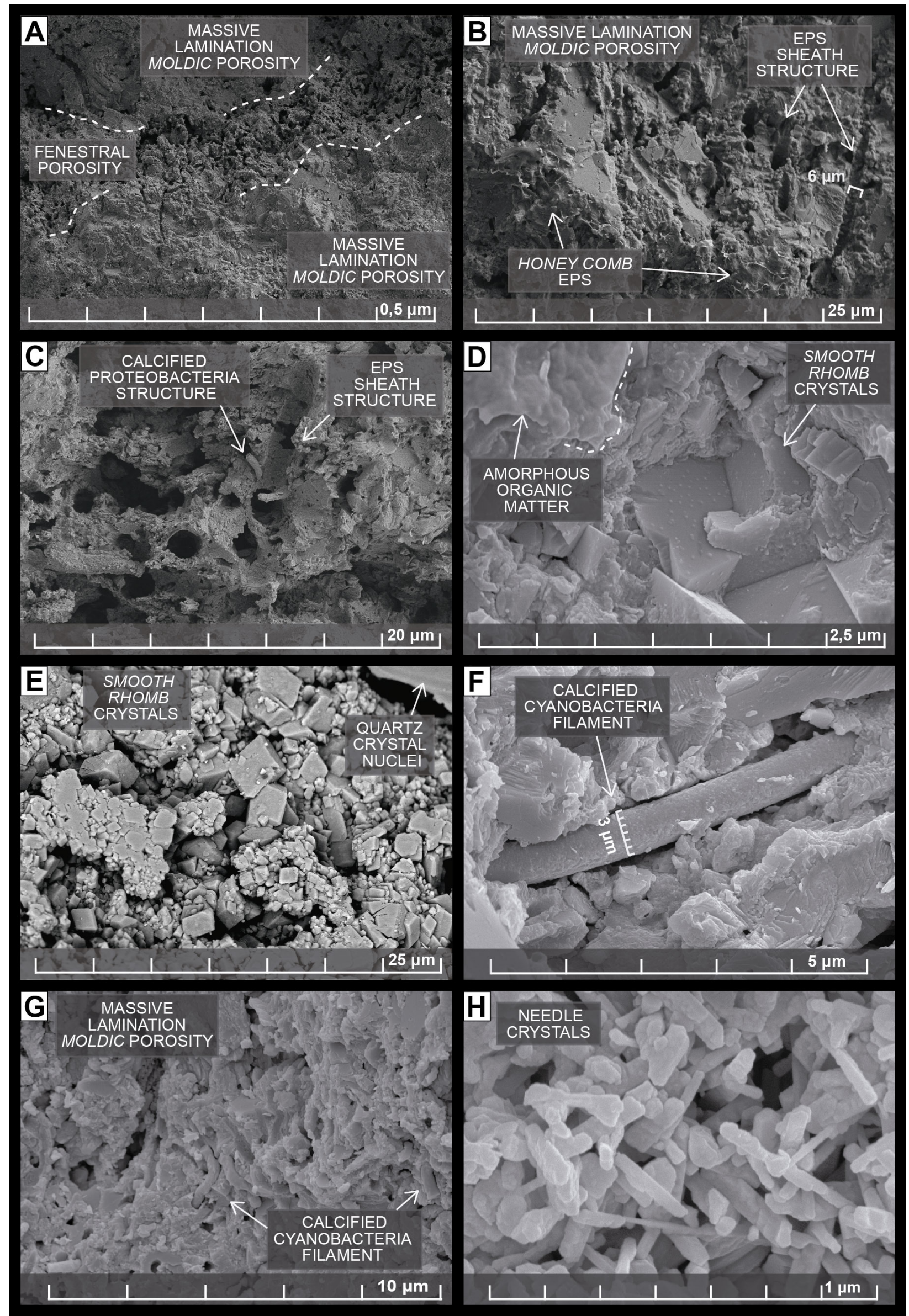

Figure 5. Massive micrite with moldic porosity. SEM photomicrograph. (A) Massive micrite layers showing highly porous layers with moldic porosity; (B) Massive lamination with moldic porosity by EPS sheath structure cyanobacteria filamentous and honeycomb EPS; (C) Moldic porosity of EPS sheath structure cyanobacteria filamentous with calcified proteobacteria structure; (D) Clusters of calcite needle crystals; (E) Smooth rhomb crystals next to a quartz crystal nucleus; (F) Smooth rhomb crystals and amorphous organic matter; (G) Massive lamination with moldic porosity and calcified cyanobacteria filament; $(\mathrm{H})$ Massive lamination with calcified cyanobacteria filament. 

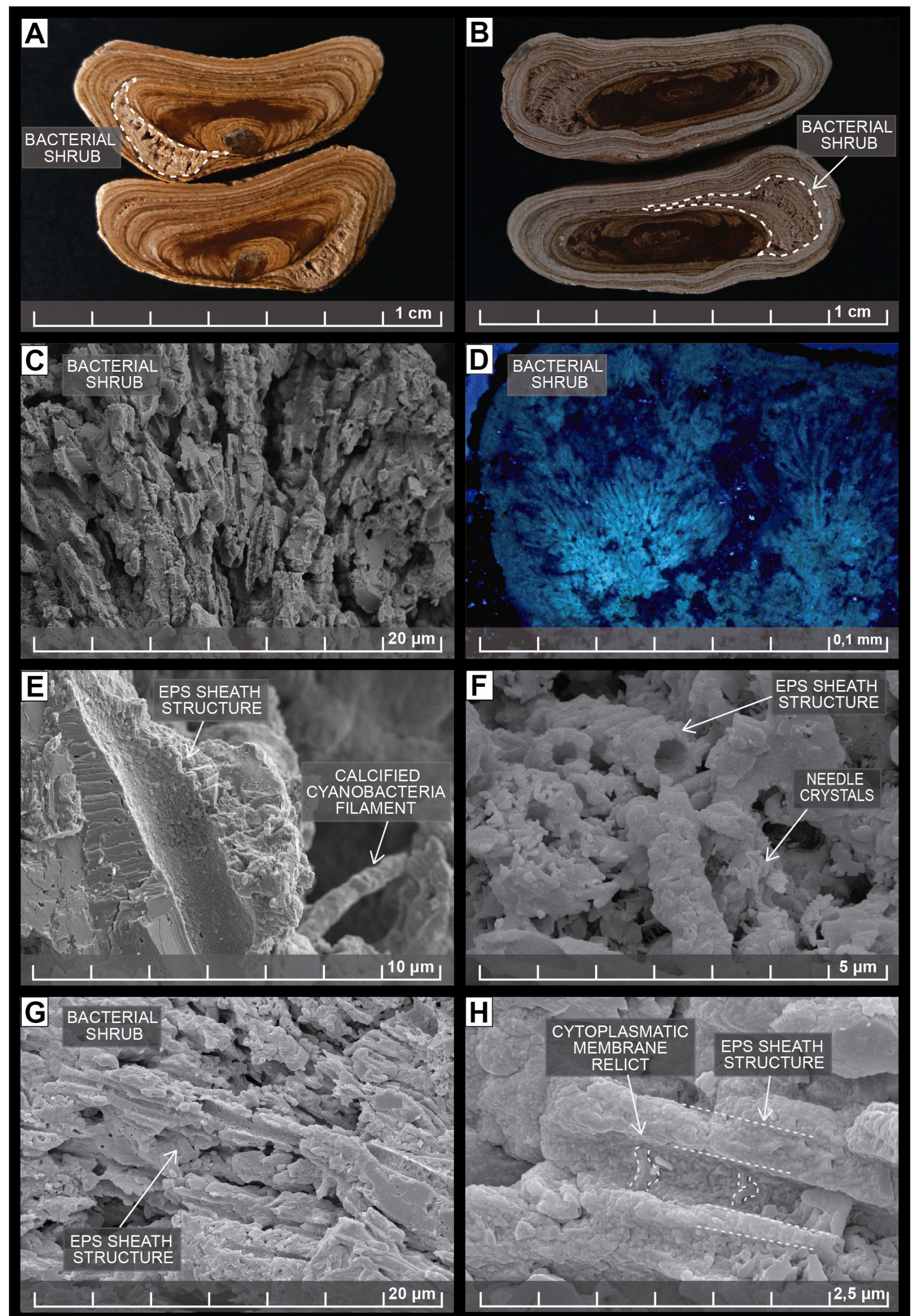

Figure 6. SEM photomicrograph and UV epifluorescence (D) of bacterial shrub structure. (A) Type 2 oncoid with bacterial shrub areas; (B) Type 3 oncoid with bacterial shrub areas; (C) Bacterial shrub structures; (D) Cyanobacteria arrangements in a bacterial shrub structure; (E) Filamentous cyanobacteria EPS sheath structure, and calcified cyanobacteria filament; (F) Filamentous cyanobacteria EPS sheath structure, and calcite needle crystals composite; (G) Filamentous cyanobacteria EPS sheath structure; (H) Detail of the relict cytoplasmatic membrane within EPS sheath structure. 
The calcite crystals show $>10 \mu \mathrm{m}$ euhedral shapes, sparse cyanobacteria calcified filaments (Fig. 6E), and needle calcite crystals (Fig. 6F). Moldic porosity can reach $18 \%$ of the sample with $\sim 100 \mu \mathrm{m}$ in length (Fig. 6G) $6 \mu \mathrm{m}$-diameter pores (Fig. 6H).

\section{Microbial activity related structures summary}

Four major types of calcite crystal structures that compound the microfacies can be described as:

- EPS sheath structure: represents specifically a calcification of the EPS sheath, without a filament preserved, occurring in both microfacies, in massive micrite as a moldic porosity and Bacterial Shrub as a tubular structure with a radial arrangement, showing a regular growth pattern on samples;

- Smooth Rhomb Crystals: represents rhombohedral crystal, occurring frequently in both microfacies and also showing a regular growth pattern along with the samples;

- Needle Crystals: observed normally in small clusters, rarely occurring without a regular pattern;

- Calcified filaments: in this situation, the filament is properly calcified without specific relation to the EPS sheath and does not form calcite structures. They rarely occur without a regular pattern.

\section{Chemical and mineralogical composition}

The energy-dispersive $\mathrm{X}$-ray spectroscopy showed the main composition of $\mathrm{Ca}, \mathrm{O}$, and $\mathrm{C},(5,000$ to 12,000 cps) while $\mathrm{Si}, \mathrm{Al}, \mathrm{K}$, and $\mathrm{Fe}$ occur in low proportions (> $1,000 \mathrm{cps}$ ) (For further detail, see supplementary material). The amorphous organic matter (Figs. 7A and 7B) occurs either in the moldic porosity (Figs. 7C and 7D) or disseminated throughout the lamination. The subsequent micrite-growth cycles trap the organic material (Figs. 7E-7H) and the later organic matter infiltrations represent a subordinate occurrence.

The bulk mineralogic composition of oncoids consists mainly of calcite and quartz, and it is similar in all studied oncoid morphology types. The bulk rock chemical composition shows $\mathrm{CaO}$ contents around $54 \%, \mathrm{SiO}_{2}$ from 0.77 to $1.35 \%$, as well as minor $\mathrm{Fe}_{2} \mathrm{O}_{3}, \mathrm{Al}_{2} \mathrm{O}_{3}$, and $\mathrm{MgO}$ (Tab. 1).

\section{Carbon and oxygen stable isotopes}

Carbon and Oxygen stable isotopes $(\delta \%$ VPDB $)$ were investigated in oncoids (from Rs and Fs), calcareous fragments $(\mathrm{Gs})$, and clays $(\mathrm{Cl})$, representing the main facies described above (Tab. 2). Bulk rock oncoid samples ( $R s$ and $F s$ ) showed isotopic ratios between -5.55 to $-6.13 \%$ o VPDB for $\delta^{13} \mathrm{C}$ and -7.37 to $-7.51 \%$ VPDB for $\delta^{18} \mathrm{O}$. The calcareous fragments $(G l)$ showed relatively more negative $\delta^{13} \mathrm{C}$ ratios around -6.33 to $-6.46 \%$ VPDB. However, $\delta^{18} \mathrm{O}$ are similar, ranging from -7.41 to $-7.82 \%$ VPDB. Dissimilar ratios were observed in clays $(\mathrm{Cl})$, where the values ranged from -3.96 to $-6.62 \%$ VPDB for $\delta^{13} \mathrm{C}$, and -8.18 to -9.02 $\%$ VPDB for $\delta^{18} \mathrm{O}$.

\section{DISCUSSION}

\section{Oncoids nucleation, growth and morphology}

The nucleation and growth of the oncoids start when the EPS allows microbial communities to attach themselves to the substrate (Decho et al.2005, Decho and Gutierrez 2017). Several surfaces have the substrate potential to trigger nucleation, such as quartz grains or Mollusca shells. Therefore, the lamination is evidence of the oncoidal growth processes, with an interbedding of bacterial activity-related structures and pores filled with amorphous organic matter.

Studies of the Rivularia haematites have shown evidence of increased productivity during Winter and poorly calcified layers during Summer (Pentecost 1978, Pentecost and Talling 1987). Considering that Rivulariaceae and Nostocaceae families are the most common oncoid-forming microorganisms (Riding 1975, Pentecost 1978, Pentecost and Talling 1987, Leinfelder and Hartkopf-Fröder 1990, Riding and Awramik 2000, Hägele et al., 2006, Shalygin et al.2018), and by morphology comparison through SEM results (Reviers 2002, Shalygin et al.2018) we interpreted that the EPS sheath structures may have originated from organisms of the Rivulariaceae family, whereas the calcified filamentous structures may be related to the Nostocaceae family.

The set of laminations are responsible for the oncoidal morphology, which has been used for environmental interpretation since they are able to provide water-energy conditions (Logan et al. 1964, Dahanayake 1978, Leinfelder and HartkopfFröder 1990) and light incidence information (Leinfelder and Hartkopf-Fröder 1990, Hägele et al. 2006).

The genesis of concentric oncoids was initially interpreted as a result of rolling of the particles in submerged environments with constant movement, leading to the spheroid rounded shapes (Logan et al. 1964, Dahanayake 1978, Flügel 2010). However, new studies have suggested that spherical and subspherical oncoids may have in situ growth, with similar-thick lamination patterns, where coarse-grained substrates enhance growth in response to light reflection at the base of the oncoids, in which agitated hydraulic conditions are not a requirement (Leinfelder and Hartkopf-Fröder 1990, Hägele et al. 2006, Zhang et al. 2015).

Studies on oncoids of the Alz river in Germany suggested that differences in light incidence may cause eccentricity of the concentric lamination and the lack of mechanical disturbances and bearing allow in situ growing processes (Hägele et al.2006). The described oncoid types have similar features to the ones described in the $\mathrm{Alz}$ river, such as different sizes of lamination causing oncoidal eccentricity (Fig. 8). Furthermore, the type 1 oncoid (concave top lacking basal lamination) does not bear evidence such as surface erosion and was likely attached to the substrate during growth. The in-situ growth implies the absence of carbonate production at the oncoid's base and may be indicative of either absence or reduced light incidence.

Type 2 may indicate that the initial oncoid nucleation stage occurred attached to the substrate and it was later detached. This process requires biofilm development and represents a 

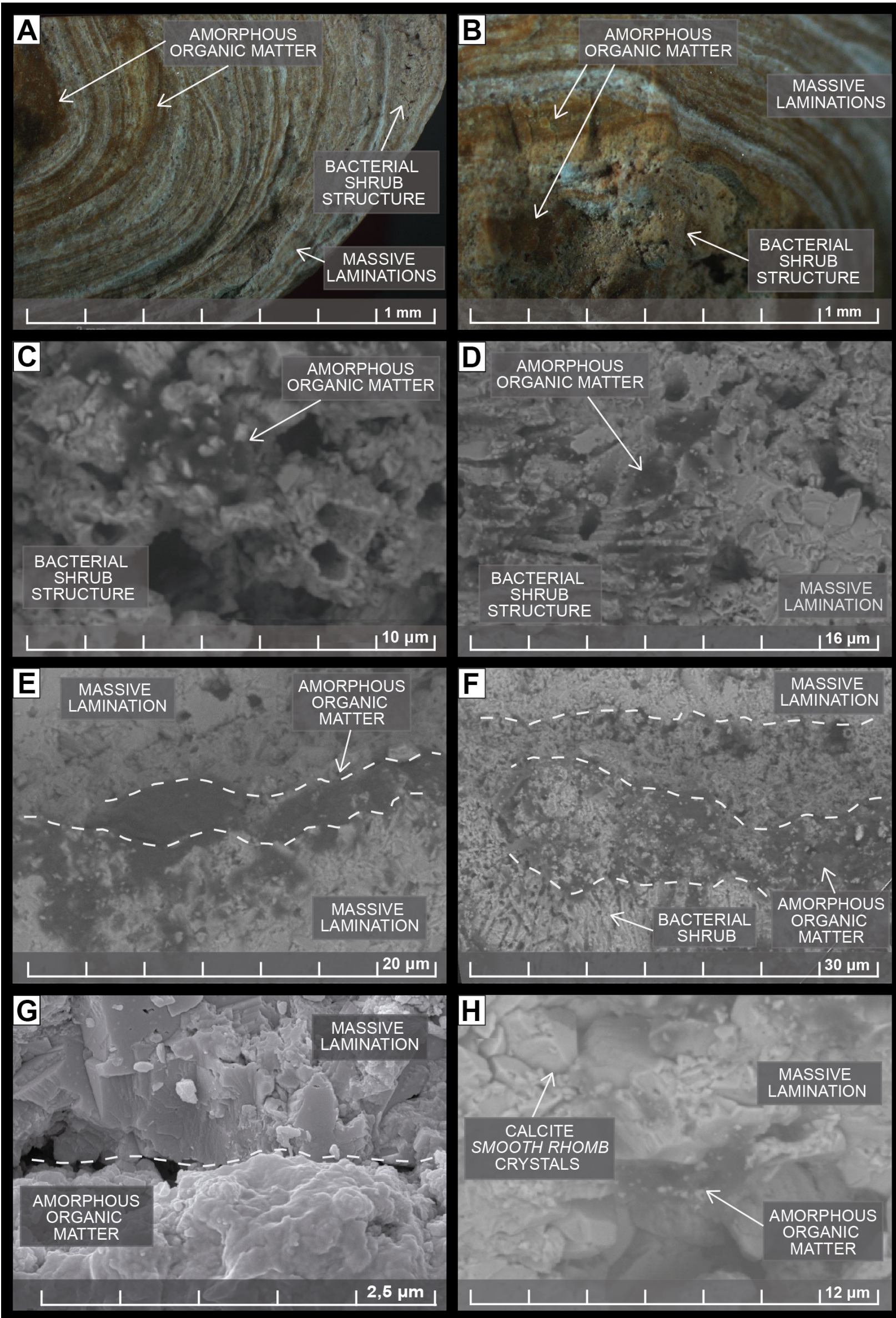

Figure 7. (A-B) Photomicrographs and SEM images of amorphous organic matter. (A) Type 2 oncoid, with an amorphous organic matter concentration near to the oncoid nuclei. Layers of organic matter also occur between massive micrite layers; (B) Type 2 oncoid, showing bacterial shrub structure around the nuclei with the amorphous organic matter between massive micrite layers; (C and D) Amorphous organic matter in bacterial shrub structure; (E) Amorphous organic matter disseminated in massive micrite layers; (F) Amorphous organic matter disseminated in the transition between massive and bacterial shrub layering; (G) Amorphous organic matter trapped by massive lamination; (H) Amorphous organic matter filling pores in massive micrite layers with smooth rhomb calcite crystals. 
Braz. J. Geol. (2022), 52(2): e2021042

Table 1. Major element distribution in Formoso River oncoids. Values in weight \% oxides.

\begin{tabular}{lrrrrrrrrrrrr}
\hline SAMPLE & $\mathbf{C a O}$ & $\mathbf{M g O}$ & $\mathbf{S i O}_{2}$ & $\mathbf{A l}_{2} \mathbf{O}_{3}$ & $\mathbf{F e}_{2} \mathbf{O}_{3}$ & $\mathbf{K}_{2} \mathbf{O}$ & $\mathbf{S r O}$ & $\mathbf{T i O}_{2}$ & $\mathbf{M n O}$ & $\mathbf{P}_{2} \mathbf{O}_{5}$ & LOI & $\mathbf{S U M}$ \\
\hline Floatstone 01 & 31.73 & 0.16 & 33.21 & 2.42 & 3.69 & 0.13 & 0.04 & 0.14 & 0.57 & 0.04 & 27.87 & 100.01 \\
Floatstone 02 & 43.72 & 0.11 & 13.76 & 0.68 & 4.31 & 0.03 & 0.05 & 0.04 & 0.71 & 0.03 & 36.20 & 99.66 \\
Oncoid 03 & 54.05 & 0.13 & 0.77 & 0.35 & 0.75 & 0.02 & 0.06 & 0.03 & 0.18 & 0.03 & 43.63 & 99.99 \\
Oncoid 04 & 53.68 & 0.08 & 1.35 & 0.41 & 0.29 & 0.02 & 0.06 & 0.03 & 0.04 & 0.02 & 43.99 & 99.96 \\
Oncoid 05 & 54.06 & 0.07 & 0.99 & 0.42 & 0.40 & 0.02 & 0.07 & 0.03 & 0.04 & 0.02 & 43.61 & 99.73 \\
\hline
\end{tabular}

Table 2. Carbon and oxygen stable isotopes ratios. Values in \%oVPDB.

\begin{tabular}{lcccccc}
\hline Code & Sample & Facies & $\delta^{\mathbf{1 3}} \mathbf{C}$ & $\mathbf{1 \sigma}\left[\delta^{\mathbf{1 3}} \mathbf{C}\right]$ & $\delta^{\mathbf{1 8}} \mathbf{O}$ & $\mathbf{1 \sigma}\left[\delta^{\mathbf{1 8}} \mathbf{O}\right]$ \\
\hline $133 / 19-01$ & Claystone & Cl & -4.58 & 0.09 & -9.02 & 0.05 \\
$133 / 19-09$ & Grainstone & Gl & -6.46 & 0.02 & -7.82 & 0.09 \\
$133 / 19-11$ & Floatstone & Fs & -6.44 & 0.02 & -7.57 & 0.06 \\
$133 / 19-12$ & Rudstone & Rs & -6.13 & 0.02 & -7.44 & 0.09 \\
$133 / 19-13$ & Rudstone & Rs & -6.22 & 0.09 & -7.41 & 0.04 \\
$133 / 19-16$ & Mudstone & Mm & -6.62 & 0.08 & -8.8 & 0.05 \\
$133 / 19-22$ & Grainstone & Gl & -6.33 & 0.07 & -7.54 & 0.05 \\
$133 / 19-23$ & Rudstone & Rs & -6.38 & 0.05 & -7.41 & 0.04 \\
$133 / 19-33$ & Floatstone & Fs & -1.44 & 0.04 & -7.56 & 0.04 \\
$133 / 19-35$ & Floatstone & Fs & -3.96 & 0.06 & -8.18 & 0.05 \\
$133 / 19-44$ & Oncoid & Rs & -5.82 & 0.05 & -7.51 & 0.06 \\
$133 / 19-45$ & Oncoid & Rs & -6.04 & 0.04 & -7.39 & 0.05 \\
$195 / 18-01$ & Oncoid & - & -5.97 & 0.04 & -7.66 & 0.05 \\
$195 / 18-02$ & Oncoid & - & -5.65 & 0.07 & -7.53 & 0.07 \\
$195 / 18-03$ & Oncoid & - & -5.55 & 0.02 & -7.37 & 0.03 \\
$195 / 18-04$ & Oncoid & - & -5.98 & 0.03 & -7.44 & -7.39 \\
$195 / 18-05$ & Oncoid & - & -5.66 & 0.03 & 0.04 \\
\hline
\end{tabular}

transition between non-concentric laminations development to fully concentric ones.

The oncoids with spherical shapes (types 3 and 4) show concentric and similar thick size lamination. This pattern suggests oncoidal growth detached from the substrate, where the concentric biofilm may indicate a similar incidence of light around the oncoid, implying bearing occurrences.

Since most oncoids were nucleated around quartz grains of 0.1 to $1 \mathrm{~mm}$, and considering the nucleation likely occurs below the deposition curve (Hjülstrom diagram), suggesting a flow velocity between 0.1 and $1 \mathrm{~cm} \cdot \mathrm{s}^{-1}$. For oncoids nucleated from grains transported as bedload, the flow velocity would be between 1 to $20 \mathrm{~cm} \cdot \mathrm{s}^{-1}$ (Nichols 2009).

Given the predominance of regular lamination in terms of format, continuity and linearity, oncoid genesis possibly occurs under a laminar flow influence. For oncoids nucleated on detrital quartz grains, only in initial nucleation stages, an estimate using the Reynolds number was proposed to infer the flow type, considering the water viscosity to be $1 \times 10^{-3}$ Pa.s, the fluid specific mass $1.0 \mathrm{~kg} . \mathrm{m}^{-3}$, the flow velocity of 0.1 to $1 \mathrm{~cm} . \mathrm{s}^{-1}$ (Hjülstrom diagram), and assuming that a laminar flow requires $\operatorname{Re}<500$, the water body depth could not exceed $50 \mathrm{~cm}$ to maintain a laminar flow (Nichols 2009).

\section{Carbon and oxygen isotopic record and significance}

Isotopic $\mathrm{C}$ and $\mathrm{O}$ ratios $(\delta \% \mathrm{VPDB})$ in riverine and paludal tufas are controlled by karst groundwater (Andrews et al. 2000, Andrews 2006). At Central-West Brazil latitude ( $21^{\circ} \mathrm{S}$ ), we can consider a similar $\delta^{18} \mathrm{O}$ to the ground and meteoric water (Gat 1971, Darling 2004) in the current climate, where continentality is the main factor that leads to relatively more negative $\delta^{18} \mathrm{O}$ values in the region (Garnett et al. 2006).

The $\delta^{18} \mathrm{O}$ ratios of $-7.30 \%$ o to $-8.00 \%$ in the studied oncoids (Tab. 2) are close to results obtained in recent and sub-recent tufas of the Formoso River (Taíka and Mimosa sites) in which the values range from $-6.50 \%$ up to $-8.50 \%$ (Oste 2017). This resembling results for ancient and recent tufa in comparison to oncoids, endorse the meteorical water source.

Regarding the stable carbon isotopes ( $\delta \% \mathrm{VPDB})$, it is mandatory to consider the degassing effect in tufas, where this continuous process might increase $\delta^{13} \mathrm{C}$ dissolved inorganic carbon (DIC) values, and consequently, influence the carbon isotopic values for tufas downstream (Pentecost and Spiro 1990). The photosynthesis effects controlled by cyanobacterial action remove the ${ }^{12} \mathrm{CO}_{2}$, resulting in the calcite ${ }^{13} \mathrm{C}$ enrichment (Pentecost and Spiro 1990, Arp et al. 2001a, Arp et al. 2001b). 




Figure 8. Illustrative scheme summarizing the four main oncoids types and their interpreted genesis conditions separated into three situations: Situation A: containing concave oncoids, type 1, representing concave oncoids, without carbonate production at the base. Situation AB: involves concave oncoids, type 2, representing a transition between A and B situations. Situation B: involves spherical oncoids, types 3 and 4, with concentric lamination and similar carbonate production around the oncoid. Oncoids with A situation genesis likely had in situ growth, partially fixed to the substrate. In contrast, oncoids with B situation genesis have grown detached from the bottom substrate, with favorable conditions that allowed similar concentric carbonate production around the oncoid, often subjected to bearing.

The higher plants photosynthesis' influence is negligible due to the oncoids' (cyanobacteria colony) inability to compete with macrophytes (Dandurand et al. 1982, Hägele et al. 2006). However, in the current tufa-system environment, higher plants influence the phytoherm facies along the rivers (Oste 2017). The abundance of $\mathrm{C} 3$ plants also indicates wet conditions, and it holds the $\delta^{13} \mathrm{C}$ around $-8.00 \%$ (Smith et al. 2004).

The $\delta^{13} \mathrm{C}$ values between -5.50 to $-6.50 \%$ in oncoids are less negative when compared with values of recent and sub-recent tufas from the Formoso river ( $-7.00 \%$ o to $-9.50 \%$ ) (Oste 2017). The less negative data for oncoids indicates a further specific microbial action (Schidlowski 2000), confirming the lack of macrophytal influence.

\section{Oncoids in Quaternary deposits at Central-West Brasil significance}

Active riverine tufas from the Formoso river formed under the same climatic conditions have different facies, interpreted as a consequence of geomorphological features in the environment that controls $\mathrm{CO}_{2}$ degassing, flow velocity, and consequently the biota development (Oste et al. 2021). In summary, there were two predominant features often described in the 
literature from the Serra da Bodoquena Region, formed under the actual climatic condition: the riverine and paludal tufas.

Subordinately, the oncoidal floatstones and rudstones were observed in alluvial terraces of the Formoso River. Oncoidal facies were described in a riverine environment at the Formoso River, cemented in a muddy matrix (Oste et al. 2021), and in the Fazenda São Geraldo's oncoids underlying unconsolidated micrites (paludal tufas environment) (Utida 2009, Oliveira et al., 2017, Utida et al. 2017). We observed oncoids underlying the paludal tufas (massive mudstone Facies), separated by an abrupt and irregular contact. These observations led us to suggest that the genesis of oncoids is not recent and may have occurred before the current time.

The described oncoids possibly had genesis at a time before the establishment of the current tufa precipitation system. In the region's rivers (Formoso and its tributary), oncoids in nucleation processes were not observed, and the current absence of oncoids in nucleation may be explained by the fact that oncoids require specific conditions for nucleation. One of the main factors is the absence of macrophytes (higher plants and green algae) and predators such as gastropods (Leinfelder and Hartkopf-Fröder 1990, Hägele et al.2006), both occuring abundantly in the region (Oliveira et al.2017, Utida et al.2017, Oste et al. 2021) these aspects can suggest a major climatic change for oncoid nucleation before the establishment of the actual climatic system. The summary of the interpreted evolution of the Formoso River carbonate precipitation system and the ages suggested for oncoid nucleation are shown in Tab. 3.

The age of the rudstone deposits or individual oncoids is still unknown, however, the paludal micrites $(\mathrm{Mm})$ that overlie the oncoidal lenses have shown $\mathrm{C}^{14}$ ages of 5,650 to 4,200 to years BP (Sallun Filho et al. 2009b) and an estimated depositional rate around $\sim 7.5 \mathrm{~cm} / 100$ years (Utida 2009). Based on these ${ }^{14} \mathrm{C}$ ages and the thickness $(5.0 \mathrm{~m})$ of the deposits, we can infer that a major paludal micrite deposition may have started around 8,500 yr BP, culminating with the lake level fall triggered by a drought period between 8,500 to 4,000 to $\mathrm{yr}$
BP (Absy et al. 1991), (Fig. 9) and thus, setting the maximum depositional age of the oncoidal lenses.

Consequently, the oncoid genesis occurred before the major paludal tufa systems establishment and may be related to the end of the Pleistocene and the beginning of the Holocene. Despite the major paludal tufas depositional episode (Boggiani et al. 2002, Oliveira et al. 2017, Utida et al. 2017), relatively small layers continue to deposit in favorable topographic and hydrological conditions (Oste et al. 2021). Calcified gastropod shells, macrophyte stalks and calcareous algae increase toward succession, indicating proliferation up the section. The lack of indicative reworking and transport features over long distances indicates that the deposition occurred near the original nucleation site.

We interpreted that oncoid nucleation possibly started after the arboreal pollen decrease in 27,000 yr BP (Ledru 1993) (Fig. 9), since oncoids are unable to compete with macrophyte plants, establishing their minimum nucleation ages where the absence of macrophyte plants and predators such as gastropods, allowing their full development (Hägele et al.2006, Zhang et al. 2015, Xiao et al.2020). Recent palinological interpretations in ${ }^{14} \mathrm{C}$ dated samples from the Laguna la Gaiba along the Paraguay River (Pantanal wetlands hydrological linked) interior of Tropical South America, also show colder and drier conditions with an open landscape with smaller trees proliferating and lower lake levels around $\sim 45,000$ and 19,500 yr BP (Whitney et al. 2011).

In addition, insolation also affects atmospheric circulation and convective intensity, and consequently the hydrological cycle (Cruz Jr. et al. 2005), oxygen isotopic record from radiocarbon on dated lacustrine sediments in Salar de Uyuni, also shows an increase in natural $\gamma$-radiation (c.p.s.) around 20,000 to $10,000 \mathrm{yr} \mathrm{BP}$, produced by Earth's precessional cycle considering the Tropical South America region (Baker et al. 2001). Although we have not seen current oncoid nucleation and growth on actual rivers and a correlation with climatic changes in Central-West Brazil, a more favorable environment

Table 3. Relatively ages interpretations, correlated to environmental conditions.

\begin{tabular}{|c|c|c|c|c|c|}
\hline Epoch & $\begin{array}{c}\text { Quaternary } \\
\text { Carbonatic } \\
\text { Deposits } \\
21^{\circ} \mathrm{S}, 56^{\circ} \mathrm{W}\end{array}$ & $\begin{array}{c}\mathrm{C}^{14} \text { AGE } \\
\text { Yr BP } \\
\text { (Sallun Filho et } \text { al. } \\
\text { 2009b) }\end{array}$ & $\begin{array}{c}\text { Relative ages } \\
\text { (Interpretative } \\
\text { correlation } \\
\text { according to Fig. 10) }\end{array}$ & $\begin{array}{c}\text { Palinological } \\
\text { record } \\
15^{\circ} \text { to } 25^{\circ} \mathrm{S} \\
45^{\circ} \text { to } 60^{\circ} \mathrm{W} \\
\text { (Ledru } 1993 \text { ) }\end{array}$ & Events \\
\hline Late Holocene & $\begin{array}{c}\text { Riverine tufa } \\
\text { (predominance) }\end{array}$ & $\begin{array}{l}2,130 \pm 60 \\
2,420 \pm 70 \\
3,410 \pm 70\end{array}$ & - & $\begin{array}{c}\text { Evidence of } \\
\text { mesophytic, } \\
\text { semideciduous forest }\end{array}$ & Modern Conditions \\
\hline Middle Holocene & $\begin{array}{c}\text { Paludal tufa } \\
\text { (predominance) }\end{array}$ & $\begin{array}{l}4,200 \pm 40 \\
5,650 \pm 50\end{array}$ & - & - & $\begin{array}{c}\text { Lake level fall } \\
\text { (Absy et al. 1991) }\end{array}$ \\
\hline Early Holocene & $\begin{array}{c}\text { Alluvial terraces } \\
\text { deposition }\end{array}$ & - & $\begin{array}{c}{ }^{*} \text { Around } 15,000 \text { to } \\
12,000 \text { yr BP }\end{array}$ & Low arboreal pollen & $\begin{array}{c}\text { Younger Dryas Event } \\
(12,900 \text { to } 11,700 \\
\text { yr BP })\end{array}$ \\
\hline \multirow[t]{2}{*}{ Late Pleistocene } & $\begin{array}{l}\text { Spread of oncoids } \\
\text { Beginning of } \\
\text { oncoids nucleation }\end{array}$ & - & $\begin{array}{c}* 15,000 \text { to } 20,000 \\
\text { yr BP } \\
{ }^{*} 25,000 \text { yr BP }\end{array}$ & $\begin{array}{c}\text { GAP } \\
\text { Sedimentation } \\
\text { ceases }\end{array}$ & $\begin{array}{l}\text { Last Glacial } \\
\text { Maximum }\end{array}$ \\
\hline & Claystone depostion & - & Before 25,000 yr BP & $\begin{array}{l}\text { Drop of arboreal } \\
\text { pollen rate }\end{array}$ & $\begin{array}{l}\text { Flooded Planicie } \\
\text { (Absy et al. 1991) }\end{array}$ \\
\hline
\end{tabular}




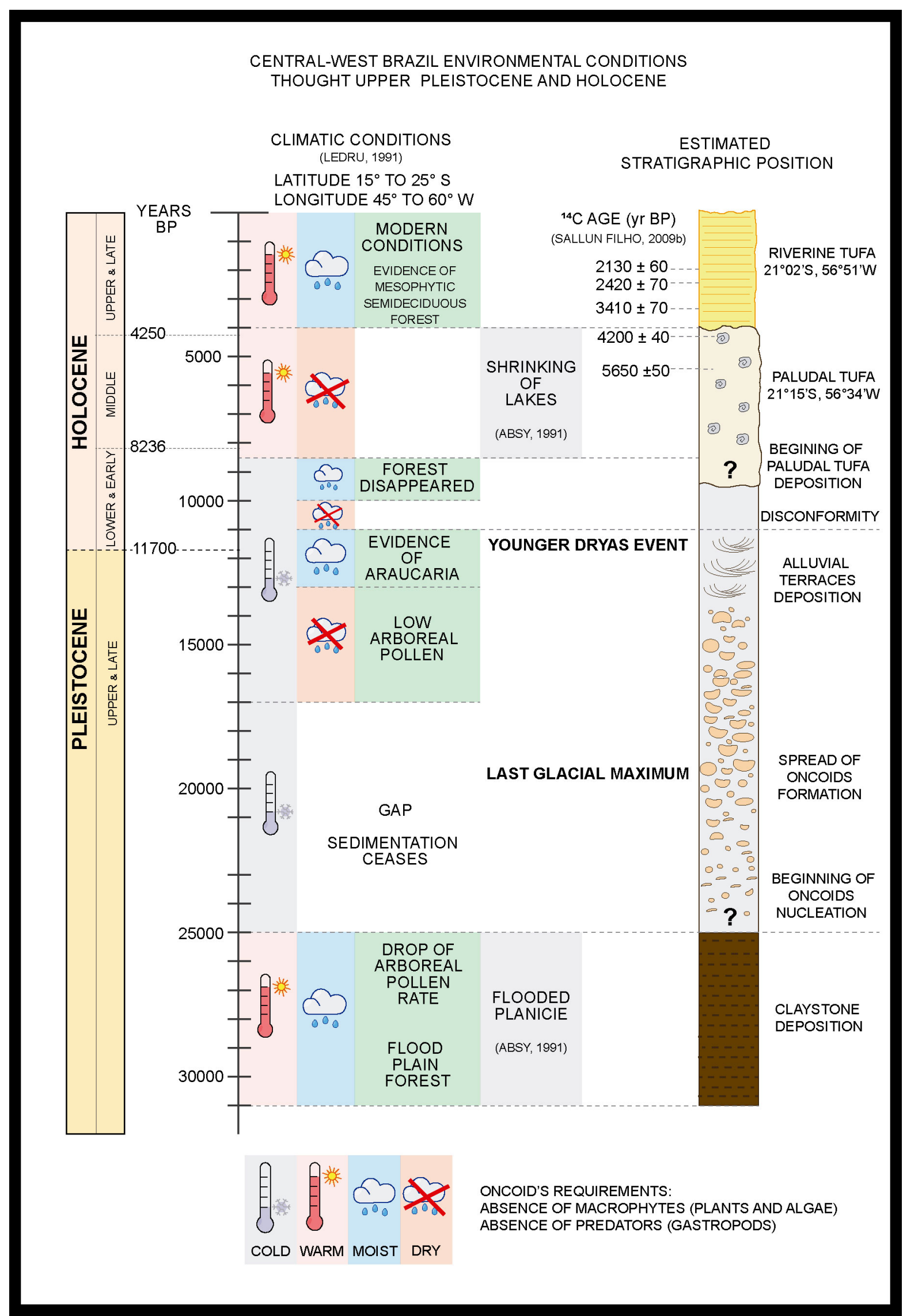

Figure 9. Interpreted climatic and environmental conditions during Upper \& Late Pleistocene and Holocene for Midwest Brazil, (Latitude $15^{\circ}$ to $25^{\circ} \mathrm{S}$, Longitude $45^{\circ}$ to $60^{\circ} \mathrm{W}$ ) based on palynological studies (Ledru 1993). The estimated stratigraphic position for oncoidal lenses based on oncoids nucleation and growing requirements (Hägele et al. 2006), outcrop features, and previous studies of carbonate deposits in the Serra da Bodoquena Formation, including phytoherm tufa from Aquidabã River (Rio Formoso Member), micrite tufa and Mollusca shells of Fazenda São Geraldo Member (Sallun Filho et al. 2009a, Sallun Filho et al. 2009b, Oliveira et al. 2017, Utida et al. 2017). An estimated deposition rate for micrites $(7,5 \mathrm{~cm}$ for 100 years) allows inferring the beginning of precipitation after the Younger Dryas Event, which culminates with low lake levels suggested by (Absy et al. 1991). Oncoids are probably older than the Younger Dryas Event (11,700 to 12,900 years BP). They may represent the depositional gap around 25,000 to 17,000 years BP. The start of oncoids nucleation probably occurred when the arboreal pollen rate decreased 27,000 years ago. 
for oncoid development in the past can be suggested, possibly around $\sim 27,000$ to $10,000 \mathrm{yr} \mathrm{BP}$.

The Bodoquena Highlands' underground karst system consists of the current tufa system's ion source (Boggiani et al. 1993, Oliveira et al. 2017), and likely provided the ion source to the oncoids' genesis in the past. The stratigraphic disposition observed in outcrops and sedimentary structures such as stratification in floatstones and rudstones, and massive structure in mudstone, corroborates the hypothesis of genesis of the oncoidal facies in a different stage compared to the paludal tufa (Mudstone facies). The oncoids appear to record a previous climatic system relatively colder and drier.

\section{CONCLUSIONS}

These oncoid occurrences represent the basal interval of the Quaternary deposits of the Serra da Bodoquena downstream plains, and probably occurred under different climatic conditions during the end of the Pleistocene and the beginning of the Holocene. We demonstrated that morphological, chemical, and isotopic aspects of oncoids coupled with stratigraphic research can provide valuable information concerning nucleation settings and environmental significance. This study interprets that oncoids grew in a shallow water environment, with a laminar flow incidence, absence of macrophytes and competing organisms.

These oncoid occurrences represent the basal interval of the Quaternary deposits of the Serra da Bodoquena downstream plains. Their genesis likely occurred under a different climatic condition during the Upper Pleistocene. The $21^{\circ} \mathrm{S}$ latitude in Brazil (Tropical South Hemisphere), was probably under colder and drier conditions (Whitney et al. 2011, Novello et al. 2017,2019 ), and oncoid nucleation possibly occurred under a shallow water body, with a reduced population of competitor organisms such as higher plants (Ledru 1993, Whitney et al. 2011), possibly under higher sunlight incidence (Baker et al. 2001, Cruz Jr. et al. 2005) culminating in favorable conditions for oncoid-forming cyanobacteria proliferation (Hägele et al. 2006, Riding 2006, Zhang et al. 2015). Detailed studies with $\mathrm{C}^{14}$ dating control could bring valuable information concerning the transition between the Pleistocene to the Holocene in Central-West Brazil (Tropical South Hemisphere), constraining the ages and evolution stages of this Quaternary carbonate system and its climatic controls.

\section{ACKNOWLEDGMENTS}

We express our gratitude to Petrobras and its partnership with the Universidade Federal do Paraná (UFPR), for providing financial support through the Microbial Project [grant number 23075.120 789/2016-11]. We are very thankful to the São Geraldo Farm help with logistics, the Centro de Microscopia Eletrônica (CME) UFPR, and Centro de Tecnologias Avançadas em Fluorescência (CTAF) UFPR for the petrographic studies.

\section{ARTICLE INFORMATION}

Manuscript ID: 20210042. Received on: 06/09/2021. Approved on: 10/08/2021.

A.C.R.: conceptualization, methodology, formal analysis, investigation, writing — original draft; L.R.S.: validation, investigation, writing review \& editing; L.F.C.: conceptualization, investigation, writing - review \& editing, supervision; A.M.B.R.: conceptualization, investigation, resources, writing — review \& editing, project administration, supervision.

Competing interests: The authors declare no competing interests.

\section{REFERENCES}

Absy M., Cleef A., Van Der Hammen T., Fournier M., Martin L., Servant M., Sifeddine A., Ferreira da Silva M., Soubies F., Suguio K., Turcq B. 1991. Mise en évidence de quatre phases d'ouverture de la forêt dense dans le sud-est del'Amazonie au cours des 60000 dernières années. Première comparaison avec d'autres régions tropicales. Comptes Rendus l'Académie des Sci. 2 Mécanique..., 312:673-678.

Andrews J.E. 2006. Palaeoclimatic records from stable isotopes in riverine tufas: Synthesis and review. Earth-Science Review, 75(1-4):85-104. https:// doi.org/10.1016/j.earscirev.2005.08.002

Andrews J.E., Pedley M., Dennis P.F. 2000. Palaeoenvironmental records in Holocene Spanish tufas: A stable isotope approach in search of reliable climatic archives. Sedimentology, 47(5):961-978. https://doi. org/10.1046/j.1365-3091.2000.00333.x

Arp G., Reimer A., Reitner J. 2001a. Photosynthesis-Induced Biofilm Calcification and Calcium Concentrations in Phanerozoic Oceans. Science, 292(5522):1701-1704. https://doi.org/10.1126/science.1057204

Arp G., Wedemeyer N., Reitner J. 2001b. Fluvial tufa formation in a hardwater creek (Deinschwanger Bach, Franconian Alb, Germany). Facies, 44:122. https://doi.org/10.1007/bf02668163

Baker P.A., Rigsby C.A., Seltzer G.O., Fritz S.C., Lowenstein T.K., Bacher N.P., Veliz C. 2001. Tropical climate changes at millennial and orbital timescales on the Bolivian Altiplano. Nature, 409:698-701. https://doi. org $/ 10.1038 / 35055524$
Berrendero E., Perona E., Mateo P. 2008. Genetic and morphological characterization of Rivularia and Calothrix (Nostocales, Cyanobacteria) from running water. International Journal of Systematic and Evolutionary Microbiology, 58(2):447-460. https://doi. org/10.1099/ijs.0.65273-0

Boggiani P.C., Coimbra A.M., Gesicki A.L.D., Sial A.N., Ferreira V.P., Ribeiro F.B., Flexor J.-M. 2002. Tufas Calcárias da Serra da Bodoquena, MS. Cachoeiras petrificadas ao longo dos rios. In: Schobbenhaus C., Campos D. de A., Queiroz E.T. de, Manfredo W., Berbert-Born M. (Eds.). Sitios Geológicos e paleontológicos do Brasil. Brasília, p. 249-259.

Boggiani P.C., Fairchild T.R., Coimbra A.M. 1993. O Grupo Corumbá (Neoproterozóico-Cambriano) na região central da Serra da Bodoquena (Faixa Paraguai), Mato Grosso do Sul. Revista Brasileira de Geociências, 23(3):301-305. https://doi. org/10.25249/0375-7536.1993233301305

Cruz Jr. F.W., Burns S.J., Karmann I., Sharp W.D., Vuille M., Cardoso A.O., Ferrari J.A., Dias P.L.S., Viana Jr. O. 2005. Insolation-driven changes in atmospheric circulation over the past 116,000 years in subtropical Brazil. Nature, 434(7029):63-66. https://doi.org/10.1038/ nature03365

Dahanayake K. 1978. Sequential position and environmental significance of different types of oncoids. Sedimentary Geology, 20:301-316. https://doi. org/10.1016/0037-0738(78)90060-X 
Dandurand J.L., Gout R., Hoefs J., Menschel G., Schott J., Usdowski E. 1982. Kinetically controlled variations of major components and carbon and oxygen isotopes in a calcite-precipitating spring. Chemical Geology, 36(34):299-315. https://doi.org/10.1016/0009-2541(82)90053-5

Darling W.G. 2004. Hydrological factors in the interpretation of stable isotopic proxy data present and past: a European perspective. Quaternary Science Review, 23(7-8):743-770. https://doi.org/10.1016/j.quascirev.2003.06.016

Decho A.W., Gutierrez T. 2017. Microbial extracellular polymeric substances (EPSs) in ocean systems. Frontiers in Microbiology, 8:1-28. https://doi. org/10.3389/fmicb.2017.00922

Decho A.W., Visscher P.T., Reid R.P. 2005. Production and cycling of natural microbial exopolymers (EPS) within a marine stromatolite. Palaeogeography, Palaeoclimatology, Palaeoecology, 219(1-2):71-86. https://doi.org/10.1016/j.palaeo.2004.10.015

Dunham R.J. 1962. Classification of carbonate rocks according to depositional texture. In: Ham W. (Ed.). Classification of Carbonate Rocks. American Association of Petroleum Geologists, p. 108-121.

Dupraz C., Reid R.P., Braissant O., Decho A.W., Norman R.S., Visscher P.T. 2009. Processes of carbonate precipitation in modern microbial mats. Earth-Science Review, 96(3):141-162. https://doi.org/10.1016/j. earscirev.2008.10.005

Dupraz C., Visscher P.T. 2005. Microbial lithification in marine stromatolites and hypersaline mats. Trends in Microbiology, 13(9):429-438. https://doi. org/10.1016/j.tim.2005.07.008

Embry A., Klovan E. 1971. A late Devonian reef tract on northeastern Banks Island, N.W.T. Bulletin of Canadian Petroleum Geology, 19(4):730-781. https://doi.org/10.35767/gscpgbull.19.4.730

Flügel E. 2010. Microfacies of Carbonate Rocks. Cham: Springer. https://doi. org/10.1007/978-3-642-03796-2

Garnett E.R., Andrews J.E., Preece R.C., Dennis P.F. 2006. Late-glacial and early Holocene climate and environment from stable isotopes in Welsh Tufa. Quaternaire, 17(2). https://doi.org/10.4000/quaternaire.742

Gat J.R. 1971. Comments on the stable isotope method in regional groundwater investigations. Water Resources Research, 7(4):980-993. https://doi.org/10.1029/WR007i004p00980

Hägele D., Leinfelder R., Grau J., Burmeister E.G., Struck U. 2006. Oncoids from the river $\mathrm{Alz}$ (southern Germany): Tiny ecosystems in a phosphoruslimited environment. Palaeogeography, Palaeoclimatology, Palaeoecology, 237(3-4):378-395. https://doi.org/10.1016/j.palaeo.2005.12.016

Ledru M.-P. 1993. Late quaternary environmental and climatic changes in Central Brazil. Quaternary Research, 39(1):90-98.https://doi.org/10.1006/ qres.1993.1011

Leinfelder R.R., Hartkopf-Fröder C. 1990. In situ accretion of concavoconvex lacustrine oncoids ('swallow nests') from the Oligocene of the Mainz Basin, Rhineland, FRG. Sedimentology, 37(2):287-301. https://doi. org/10.1111/j.1365-3091.1990.tb00960.x

Logan B.W., RezakR., Ginsburg R.N. 1964. Classification and Environmental significance of algal stromatolites. Journal of Geology, 72(1):68-83. https:// doi.org/10.1086/626965

Merz M.U.E. 1992. The biology of carbonate precipitation by cyanobacteria. Facies, 26:81-101. https://doi.org/10.1007/BF02539795

Merz-Preiß M., Riding R. 1999. Cyanobacterial tufa calcification in two freshwater streams: Ambient environment, chemical thresholds and biological processes. Sedimentary Geology, 126(1-4):103-124. https://doi. org/10.1016/S0037-0738(99)00035-4

Nichols G., 2009. Rivers and alluvial fans. In: Nichols, G. (Ed.). Sedimentology and stratigraphy. Oxford, Wiley-Blackwell, p. 129-149.

Novello V.F., Cruz F.W., Mcglue M.M., Wong C.I., Ward B.M., Vuille M., Santos R.A., Jaqueto P., Pessenda L.C.R., Atorre T., Ribeiro L.M.A.L., Karmann I., Barreto E.S., Cheng H., Edwards R.L., Paula M.S., Scholz D. 2019. Vegetation and environmental changes in tropical South America from the last glacial to the Holocene documented by multiple cave sediment proxies. Earth and Planetary Science Letters, 524:115717. https://doi.org/10.1016/j.epsl.2019.115717

Novello V.F., Cruz F.W., Vuille M., Stríkis N.M., Edwards R.L., Cheng H., Emerick S., Paula M.S. De, Li X., Barreto E.D.S., Karmann I., Santos R.V. 2017. A highresolution history of the South American Monsoon from Last Glacial Maximum to the Holocene. Scientific Reports, 7:44267.https://doi.org/10.1038/srep44267
Oliveira E.C. de, Rossetti D.F., Utida G. 2017. Paleoenvironmental evolution of continental carbonates in West-Central Brazil. Anais da Academia Brasileira de Ciências, 89(Suppl. 1):407-429. https://doi. org/10.1590/0001-3765201720160584

Oren A. 2015. Cyanobacteria in hypersaline environments: biodiversity and physiological properties. Biodiversity and Conservation, 24:781-798. https://doi.org/10.1007/s10531-015-0882-z

Oste J. 2017. Caracterização geoquímica dos depósitos tipo Tufa do Quaternário da Formação Serra da Bodoquena, Membro Rio Formoso-MS. Curitiba: Universidade Federal do Paraná.

Oste J.T.F., Rodríguez-Berriguete Á., Dal Bó P.F. 2021. Depositional and environmental controlling factors on the genesis of Quaternary tufa deposits from Bonito region, Central-West Brazil. Sedimentary Geology, 413:105824. https://doi.org/10.1016/j.sedgeo.2020.105824

Pentecost A. 1978. Blue-green algae and freshwater carbonate deposits Proceedings of the Royal Society B, 200(1138):43-61. https://doi. org/10.1098/rspb.1978.0004

Pentecost A., Spiro B. 1990. Stable carbon and oxygen isotope composition of calcites associated with modern freshwater cyanobacteria and algae. Geomicrobiology Journal, 8(1):17-26. https://doi. org/10.1080/01490459009377875

Pentecost A., Talling J.F. 1987. Growth and calcification of the freshwater cyanobacterium Rivularia haematites. Proceedings of the Royal Society B, 232(1266):125-136. https://doi.org/10.1098/rspb.1987.0064

Perona E., Mateo P. 2006. Benthic cyanobacterial assemblages as indicators of nutrient enrichment regimes in a Spanish river. Acta Hydrochimica et Hydrobiologica, 34(1-2):67-72. https://doi.org/10.1002/aheh.200500611

Reviers B. 2002. Divisão Cyanophyta. In: Reviers B. (Ed.). Biologia e filogenia das algas. Porto Alegre: Artmed. p. 21-33.

Riding R. 1975. Girvanella and other algae as depth indicators. Lethaia, 8(2):173-179. https://doi.org/10.1111/j.1502-3931.1975.tb01310.x

Riding R. 2006. Cyanobacterial calcification, carbon dioxide concentrating mechanisms, and Proterozoic-Cambrian changes in atmospheric composition. Geobiology, 4(4):299-316. https://doi. org/10.1111/j.1472-4669.2006.00087.x

Riding R.E., Awramik S.M. 2000. Microbial sediments. New York: Springer https://doi.org/10.1007/978-3-662-04036-2

Sallun Filho W., Karmann I., Boggiani P.C., Petri S., Cristalli P. de S. Utida G. 2009a. A deposição de tufas quaternárias no estado de Mato Grosso do Sul: proposta de definição da formação Serra da Bodoquena. Geologia USP. Série Científica, 9(3):47-60. https://doi.org/10.5327/ z1519-874x2009000300003

Sallun Filho W., Karmann I., Sallun A.E.M., Suguio K.2009b. Quaternary tufa in the Serra da Bodoquena Karst, West-Central Brazil: Evidence of wet period. In: IOP Conference Series: Earth and Environmental Science. Proceedings ... IOP, p. 072055. https://doi.org/10.1088/1755-1307/6/7/072055

Schidlowski M. 2000. Carbon isotopes and microbial sediments. In: Riding R.E., Awramik S.M. (Eds.). Microbial sediments. New York: Microbial Sediments. Springer, p. 84-95.

Seltzer G.O., Rodbell D.T., Baker P.A., Fritz S.C., Tapia P.M., Rowe H.D. Dunbar R.B. 2014. Early Warming of Tropical South America at the Las Glacial-Interglacial Transition. Science, 296(5573):1685-1686. https:// doi.org/10.1126/science. 1070136

Sequero C., Aurell M., Bádenas B. 2020. Oncoid distribution in the shallow domains of a Kimmeridgian carbonate ramp (Late Jurassic, NE Spain). Sedimentary Geology, 398:105585. https://doi.org/10.1016/j. sedgeo.2019.105585

Shalygin S., Pietrasiak N., Gomez F., Mlewski C., Gerard E., Johansen J.R. 2018. Rivularia halophila sp. nov. (Nostocales, Cyanobacteria): the first species of Rivularia described with the modern polyphasic approach. European Journal of Phycology, 53(4):537-548. https://doi.org/10.1080/0 9670262.2018.1479887

Smith J.R., Giegengack R., Schwarcz H.P. 2004. Constraints on Pleistocene pluvial climates through stable-isotope analysis of fossil-spring tufas and associated gastropods, Kharga Oasis, Egypt. Palaeogeography, Palaeoclimatology, Palaeoecology, 206(1-2):157-175. https://doi. org/10.1016/j.palaeo.2004.01.021 
Utida G. 2009. Fósseis em micritos Quaternários da Serra da Bodoquena, Bonito-MS e sua aplicação em estudos paleoambientais. São Paulo: Universidade de São Paulo.

Utida G., Oliveira E.C., Tucker M., Petri S., Boggiani P.C. 2017. Palaeoenvironmental interpretations based on molluscs from mid-Holocene lacustrine limestones, Mato Grosso do Sul, Brazil. Quaternary International, 437(Part A):186-198. https://doi.org/10.1016/j.quaint.2016.11.007

Védrine S., Strasser A., Hug W. 2007. Oncoid growth and distribution controlled by sea-level $\mathrm{X}$ uctuations and climate (Late Oxfordian, Swiss Jura Mountains). Facies, 53:535-552. https://doi.org/10.1007/ s10347-007-0114-4

Wang X., Auler A.S., Edwards R.L., Cheng H., Cristalli P.S., Smart P.L., Richards D.A., Shen C.-C. 2004. Wet periods in northeastern Brazil over the past $210 \mathrm{kyr}$ linked to distant climate anomalies. Nature, 432:740-743. https://doi.org/10.1038/nature03067
Whitney B.S., Mayle F.E., Punyasena S.W., Fitzpatrick K.A., Burn M.J., Guillen R., Chavez E., Mann D., Pennington R.T., Metcalfe S.E. 2011. A $45 \mathrm{kyr}$ palaeoclimate record from the lowland interior of tropical South America. Palaeogeography, Palaeoclimatology, Palaeoecology, 307(14):177-192. https://doi.org/10.1016/j.palaeo.2011.05.012

Xiao E., Mei M., Jiang S., Zafar T. 2020. Morphology and features of Cambrian oncoids and responses to palaeogeography of the North China Platform. Journal of Palaeogeography, 9:7. https://doi.org/10.1186/ s42501-020-0055-1

Zhang W., Shi X., Jiang G., Tang D., Wang X. 2015. Mass-occurrence of oncoids at the Cambrian Series 2-Series 3 transition: Implications for microbial resurgence following an Early Cambrian extinction. Gondwana Research, 28(1):432-450. https://doi.org/10.1016/j. gr.2014.03.015

\section{ERRATUM}

https://doi.org/10.1590/2317-4889202220210042erratum

In the manuscript "Continental freshwater carbonate coated grains: oncoids in Quaternary deposits of the Serra da Bodoquena region, Central-West Brazil”, DOI: 10.1590/2317-4889202220210042, published in the Braz. J. Geol., 52(2):20210042:

\section{Where it reads:}

(C) 2021 The authors. This is an open access article distributed under the terms of the Creative Commons license.

\section{It should read:}

(C) 2022 The authors. This is an open access article distributed under the terms of the Creative Commons license.

\section{Where it reads:}

Braz. J. Geol. (2021), 52(2): e20200042

\section{It should read:}

Braz. J. Geol. (2022), 52(2): e20200042 